\title{
In Situ Formation of $\mathrm{TiB}_{2}$ Nanoparticles for Enhanced Dehydrogenation/Hydrogenation Reaction Kinetics of $\mathrm{LiBH}_{4}-\mathrm{MgH}_{2}$ as a Reversible Solid-State Hydrogen Storage Composite System
}

Fahim Karimi, ${ }^{*}+$ María V. C. Riglos, ${ }^{\ddagger}$ Antonio Santoru, ${ }^{\dagger}$ Armin Hoell, ${ }^{\|}$Vikram S. Raghuwanshi, Chiara Milanese, $^{\perp}$ Nils Bergemann, ${ }^{\dagger}$ Claudio Pistidda, ${ }^{\dagger}$ Pau Nolis, ${ }^{\#} \oplus$ Maria D. Baro, ${ }^{\nabla}$ Gökhan Gizer, ${ }^{\dagger}$ Thi-Thu Le, ${ }^{\dagger}$ P. Klaus Pranzas, ${ }^{\dagger}$ Martin Dornheim, ${ }^{\dagger}$ Thomas Klassen, ${ }^{\dagger}$ Andreas Schreyer, ${ }^{\circ}$ and Julián Puszkiel ${ }^{\dagger, \S}$

\footnotetext{
${ }^{\dagger}$ Department of Nanotechnology, Institute of Materials Research, Helmholtz-Zentrum Geesthacht, Max-Planck-Straße 1, 21502 Geesthacht, Germany

${ }^{\ddagger}$ Department of Metalphysics and ${ }^{\S}$ Department of Physicochemistry of Materials, Consejo Nacional de Investigaciones Científicas y Técnicas (CONICET) y Centro Atómico Bariloche, Av. Bustillo km 9500, R8402AGP S.C. de Bariloche, Argentina

"Institut für Nanospektroskopie, Helmholtz-Zentrum Berlin für Materialien und Energie, Hahn-Meitner-Platz 1, 14109 Berlin, Germany

${ }^{\perp}$ Pavia Hydrogen Lab, C.S.G.I. and Chemistry Department, Physical Chemistry Section, University of Pavia, Viale Taramelli, 16, 27100 Pavia, Italy

${ }^{\#}$ Servei de Ressonància Magnètica Nuclear and ${ }^{\nabla}$ Departament de Física, Facultat de Ciències, Universitat Autònoma de Barcelona, E-08193 Cerdanyola del Vallès, Barcelona, Spain

OEuropean Spallation Source ERIC, P.O. Box 176, S-22100 Lund, Sweden
}

Supporting Information

\begin{abstract}
To enhance the dehydrogenation/rehydrogenation kinetic behavior of the $\mathrm{LiBH}_{4}-\mathrm{MgH}_{2}$ composite system, $\mathrm{TiF}_{4}$ is used as an additive. The effect of this additive on the hydride composite system has been studied by means of laboratory and advanced synchrotron techniques. Investigations on the synthesis and mechanism upon hydrogen interaction show that the addition of $\mathrm{TiF}_{4}$ to the $\mathrm{LiBH}_{4}-\mathrm{MgH}_{2}$ composite system during the milling procedure leads to the in situ formation of well-distributed nanosized $\mathrm{TiB}_{2}$ particles. These $\mathrm{TiB}_{2}$ nanoparticles act as nucleation agents for the formation of $\mathrm{MgB}_{2}$ upon dehydrogenation process of the hydride composite system. The effect of $\mathrm{TiB}_{2}$ nanoparticles is maintained upon cycling.
\end{abstract}

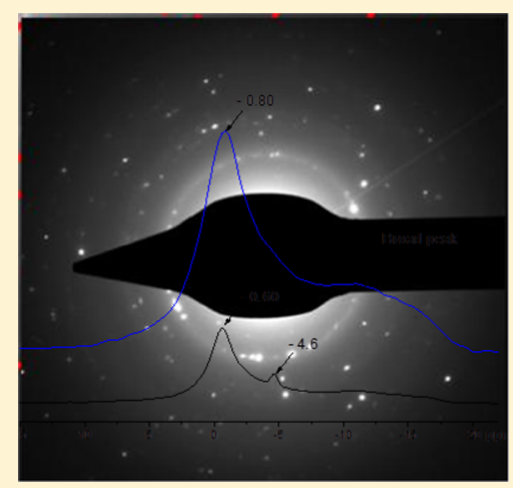

\section{INTRODUCTION}

Complex metal hydrides are considered as potential candidates for hydrogen storage. ${ }^{1,2}$ They provide an efficient and safe way to store hydrogen in mobile applications in comparison to hydrogen stored in gaseous or liquid state. ${ }^{3}$ Among all complex hydrides, $\mathrm{LiBH}_{4}$ has been widely investigated in the past decade. $^{4-22}$ This is due to its high gravimetric and volumetric hydrogen storage capacities, i.e., $18.4 \mathrm{wt} \%$ and $121 \mathrm{~kg} / \mathrm{m}^{3}$, respectively. ${ }^{23}$ Nonetheless, the thermodynamic stability of $\mathrm{LiBH}_{4}$ precludes the reversible reaction with hydrogen at moderate temperatures and pressures. ${ }^{24} \mathrm{LiBH}_{4}$ releases hydrogen above its melting point $\left(275{ }^{\circ} \mathrm{C}\right)^{25}$ at temperatures between 480 and $490{ }^{\circ} \mathrm{C}$ through the reaction (1): $\mathrm{LiBH}_{4} \rightarrow \mathrm{B}$ $+\mathrm{LiH}+1.5 \mathrm{H}_{2}\left(\Delta \mathrm{H}=94 \mathrm{~kJ} / \mathrm{mol} \mathrm{H}_{2}\right)$ and its rehydrogenation occurs only above $650{ }^{\circ} \mathrm{C}$ and 150 bar of hydrogen pressure. ${ }^{4,5,22}$ Furthermore, highly toxic borane compounds can be formed during the dehydrogenation process of $\mathrm{LiBH}_{4} \cdot{ }^{18}$ Many attempts were taken to face the poor reversibility and sluggish rehydrogenation kinetic of this system. ${ }^{18-21} \mathrm{~A}$ breakthrough was achieved using the concept of reactive hydride composite (RHC) ${ }^{26,27}$ In this approach, a highly stable complex hydride such as $\mathrm{LiBH}_{4}$ is mixed with a less stable binary hydride like $\mathrm{MgH}_{2}\left(74 \mathrm{~kJ} / \mathrm{mol} \mathrm{H}_{2}\right)$ to reduce the overall thermodynamic stability of the composite system. ${ }^{26-39}$ The stoichiometric hydride composite system $2 \mathrm{LiBH}_{4}+\mathrm{MgH}_{2}(\mathrm{Li}-$ RHC) has a theoretical gravimetric capacity of $11.5 \mathrm{wt} \%$ and a theoretical reaction enthalpy of $45.9 \mathrm{~kJ} / \mathrm{mol} \mathrm{H}_{2}$, based on reaction (2): $2 \mathrm{LiBH}_{4}+\mathrm{MgH}_{2} \leftrightarrows 2 \mathrm{LiH}+\mathrm{MgB}_{2}+4 \mathrm{H}_{2}$. Thus,

Received: March 7, 2018

Revised: $\quad$ May 5, 2018

Published: May 9, 2018 
the overall thermodynamic stability of this system is reduced in comparison to reaction (1). This is mainly due to the exothermal formation of $\mathrm{MgB}_{2}$ during the desorption process. Therefore, the formation of $\mathrm{MgB}_{2}$ is the driving force for stabilizing the decomposition products of $\mathrm{LiBH}_{4}$. Experimentally, however, the dehydrogenation reaction of the Li-RHC system does not occur according to reaction (2). It rather decomposes in two reaction steps according to the following reaction (3): $2 \mathrm{LiBH}_{4}+\mathrm{MgH}_{2} \rightarrow \mathrm{Mg}+2 \mathrm{LiBH}_{4}+\mathrm{H}_{2} \rightarrow 2 \mathrm{LiH}+$ $\mathrm{MgB}_{2}+4 \mathrm{H}_{2} \cdot{ }^{28}$ Furthermore, this reaction only occurs at hydrogen backpressures higher than 3 bar and $400{ }^{\circ} \mathrm{C}$. At hydrogen backpressures lower than 3 bar, this composite system decomposes independently, and $\mathrm{MgB}_{2}$ is not formed. ${ }^{40,41}$ In recent years, notable improvements in the dehydrogenation/hydrogenation kinetic behavior of RHCs have been achieved by the addition of transition metals halides. $^{42-52}$

In this work, the effect of $\mathrm{TiF}_{4}$ as an additive in the $\mathrm{Li}-\mathrm{RHC}$ is investigated. The addition of $\mathrm{TiF}_{4}$ in the $\mathrm{Li}-\mathrm{RHC}$ is motivated by the fact that titanium and fluorine have one of the lowest atomic masses among transition metals and halides, respectively, which leads to a small loss in gravimetric hydrogen storage capacity of the composite system. Systematic, and extensive experimental investigations were conducted in this work by the use of laboratory and advanced synchrotron techniques to shed some light on the reasons hidden behind the catalytic effect of $\mathrm{TiF}_{4}$ in the Li-RHC system.

The results obtained in this work contribute to the fundamental understanding of the mechanism of nanosized transition metal borides and their effects on the hydride composite systems.

\section{EXPERIMENTAL SECTION}

$\mathrm{LiBH}_{4}$ powder (purity >90\%), $\mathrm{MgH}_{2}$ (purity >95\%), and titanium fluoride $\left(\mathrm{TiF}_{4}\right.$, purity $\left.>99.9 \%\right)$ were purchased from Alfa Aesar company and used as starting materials. $2 \mathrm{LiBH}_{4}+$ $\mathrm{MgH}_{2}$ mixtures were prepared with and without additive $\left(\mathrm{TiF}_{4}\right)$ by high energy ball milling in a SPEX 8000 mixer mill using a stainless steel vial and balls, respectively. The ball-to-powder ratio was chosen to be $10: 1$. In the first step, $\mathrm{MgH}_{2}$ was premilled for $5 \mathrm{~h}$. Subsequently, it was mixed with $2 \mathrm{LiBH}_{4}$ or $2 \mathrm{LiBH}_{4}+0.1 \mathrm{TiF}_{4}$, and the mixture was further milled for additional $5 \mathrm{~h}$. After milling, $2 \mathrm{LiBH}_{4}+\mathrm{MgH}_{2}+0.1 \mathrm{TiF}_{4}$ material was subjected to a gas phase analysis. For this, a Hiden Analytical HAL 201 Mass-Spectrometer was used.

Hydrogen kinetic behaviors of the pure and doped sample were assessed in a commercial Sievert's type apparatus (PCTpro 2000). The parameters for volumetric measurements were set to $390{ }^{\circ} \mathrm{C}$ at 4 bar $\mathrm{H}_{2}$ for desorption and $350{ }^{\circ} \mathrm{C}$ at 50 bar $\mathrm{H}_{2}$ for absorption. First, the materials in hydrogenated state were nonisothermally dehydrogenated with a temperature ramp set to $3{ }^{\circ} \mathrm{C} / \mathrm{min}$ and then two hydrogenation/dehydrogenation cycles in isothermal conditions were preformed. Coupled calorimetric-volumetric measurements of $2 \mathrm{LiBH}_{4}+\mathrm{MgH}_{2}+$ $0.1 \mathrm{TiF}_{4}$ composite system were performed by connecting a PCT-Pro instrument with a Sensys high-pressure differential scanning calorimeter (Setaram, HP-DSC, France). The experimental parameters were heating ramp at $3{ }^{\circ} \mathrm{C} / \mathrm{min}$, backpressure of 4 bar $\mathrm{H}_{2}$, and final temperature of about 500 ${ }^{\circ} \mathrm{C}$.

Ex situ laboratory X-ray diffraction (XRD) were collected with a Bruker D8 Advance diffractometer in the BraggBrentano geometry using a General Area detector and a $\mathrm{Cu}$ X- ray source. The sample was investigated using an airtight sample holder from Bruker. The incoherent scattering of the poly(methyl methacrylate) dome is responsible for the bump observed at low angles in all the diffractograms.

In situ synchrotron radiation X-ray powder diffraction (in situ SR-XPD) measurements were conducted at the powder diffraction beamline D3 at HASYLAB (in DESY, Hamburg, Germany). Sample preparation was carried out in a glovebox under inert conditions. A small amount of sample was charged in a single crystal sapphire capillary. The capillary, subsequently, was mounted in a high-pressure cell and exposed to a monochromatic synchrotron beam. The wavelength of the incident photons was set to about $0.5 \AA$. The sample was heated up by a tungsten wire under the capillary, whereas the sample temperature was measured by a thermocouple and controlled with a proportional-integral-derivative regulator. The diffracted intensities were collected by using a MarCCD165 area detector. The acquired two-dimensional patterns were further processed and integrated to one-dimensional (1D) patterns using the program Fit2D. ${ }^{53}$

Anomalous small-angle scattering (ASAXS) measurements were acquired at the 7T-MPW beamline at the synchrotron radiation facility BESSY II (HZB, Berlin, Germany). ${ }^{54}$ The beamline was equipped with a $\mathrm{Si}_{111}$ double-crystal monochromator and a pair of retractable collimating/focusing mirrors optics, leading to a resolution of $\Delta E / E \sim 2 \times 10^{-4}$. A multiwire proportional counter gas detector $\left(20 \times 20 \mathrm{~cm}^{2}\right.$, in size) was used to record the scattering data. All the samples were put into circular holes $(5 \mathrm{~mm}$ in diameter) of a molybdenum holder and sealed with Kapton tape to avoid any oxidation. Two sample-to-detector distances $\left(D_{\min }=780\right.$ $\mathrm{mm}$ and $\mathrm{D}_{\max }=3800 \mathrm{~mm}$ ) were chosen to cover the maximum experimentally accessible scattering vector $(q)$ range. To separate the resonant scattering of Ti-containing nanostructures, all the measurements were carried out close to the $\mathrm{K}$ absorption edge of titanium $(4966 \mathrm{eV}) .{ }^{55}$ All the selected energies with their corresponding anomalous dispersion factors are listed in Table $1 .{ }^{56}$

Table 1. Selected Energies for ASAXS Measurements at Titanium K-Edge $(4966 \mathrm{eV})$ and the Corresponding Anomalous Dispersion Coefficients

$\begin{array}{cccc}\text { element } & \text { energy }(\mathrm{eV}) & f^{\prime} & f^{\prime \prime} \\ \text { E1 } & 4600 & -2.427 & 0.508 \\ \text { E2 } & 4905 & -4.214 & 0.454 \\ \text { E3 } & 4955 & -6.059 & 0.462 \\ \text { E4 } & 4964 & -7.798 & 0.587\end{array}$

The raw data were processed using the software provided at the beamline. All the SAXS measurements were integrated and then corrected for detector sensitivity and transmission. Measured intensities were then subtracted by dark current and background. For each measurement, a glassy carbon (with a thickness of $90 \mu \mathrm{m}$ ) and a silver-behenate foil was measured to put the scattering intensities onto absolute scale and to calibrate the $q$-axis, respectively. Furthermore, energy-dependent inelastic scattering ${ }^{57}$ at high $q$-values were subtracted by following the Porod law. The resonant scattering of $\mathrm{Ti}$ containing structures was separated using the method of Goerigk et al. ${ }^{58}$

The X-ray absorption spectroscopy (XAS) data were collected at the beamline A1 at HASYLAB (DESY, Hamburg, 
Germany). The samples were mixed with cellulose $(\sim 50 \mathrm{mg})$ in a mortar and mechanically pressed (with 5 bar) into pellets 10 $\mathrm{mm}$ in size. These pellets were fixed in a circular hole of an aluminum sample holder and sealed with Kapton tapes $(55 \mu \mathrm{m}$, in thickness) to avoid any oxidation of the samples. All the XAS measurements were collected simultaneously in transmission and in fluorescence mode, respectively. The XAS data processing and analysis were carried out by using "IFEFFIT" software package. ${ }^{59}$

The transmission electron microscopy (TEM) characterization was performed in FEI TECNAI $\mathrm{G}^{2}$ machine using 200 $\mathrm{kV}$, point resolution: $0.12 \mathrm{~nm}$ and field emission gun. Dark field (DF) imaging technique was used to distinguish different phases by their diffraction. $\mathrm{MgB}_{2}$ particles were highlighted by selecting one or more of the following $\mathrm{MgB}_{2}$ phase's intense reflections ( $h k l)$ planes: (101), having $|g|=4.7 \mathrm{~nm}^{-1},(002)$, having $|g|=5.68 \mathrm{~nm}^{-1}$, and (110), having $|g|=6.49 \mathrm{~nm}^{-1}$. In the case of the additive $\left(\mathrm{TiF}_{4}\right)$, the DF images were obtained by selecting the intense reflections from the following plane families: $(101)_{\mathrm{TiB}_{2}}$, having $|g|=4.9 \mathrm{~nm}^{-1},(002)_{\mathrm{TiB}_{2}}$, having $|g|=$ $6.19 \mathrm{~nm}^{-1}$. Size measurements on every particle were performed by means of an interpolated polygon tool from iTEM software ${ }^{60}$ and the values that took into account were those from mean diameter measurements. High-resolution transmission electron microscopy (HR-TEM) images were obtained with a magnification higher than $M>300 \mathrm{k} \times$. In HRTEM images, fast Fourier transform was performed by Digital Micrograph software ${ }^{61}$ to obtain the diffraction patterns. Then, the experimental diffraction patterns were compared with the simulated ones obtained by JEMS software.. ${ }^{62}$ Samples for TEM were prepared by dispersing a small amount of powder in hexane and then ultrasonicating the suspension during $10 \mathrm{~min}$. A drop of this suspension was deposited over a commercial copper grid for TEM coated with a Formvar support film. The samples were exposed to air during a short time.

${ }^{11} \mathrm{~B}$ solid-state NMR measurements were carried out on a Bruker Avance $400 \mathrm{MHz}$ spectrometer with a wide bore $9.4 \mathrm{~T}$ magnet and employing a boron-free Bruker $4 \mathrm{~mm}$ CPMAS probe. The spectral frequency was $128.33 \mathrm{MHz}$ for the ${ }^{11} \mathrm{~B}$ nucleus, and the NMR shifts are reported in parts per million (ppm) externally referenced to $\mathrm{BF}_{3} \mathrm{Et}_{2} \mathrm{O}$. The powder materials were packed into $4 \mathrm{~mm} \mathrm{ZrO}_{2}$ rotors in an argon-filled glovebox and sealed with tight-fitting Kel-F caps. The one-dimensional (1D) ${ }^{11} \mathrm{~B}\{1 \mathrm{H}\}$ magic-angle spinning (MAS) NMR spectra were acquired after a $2.7 \mu \mathrm{s}$ single $\pi / 2$ pulse (corresponding to a radio field strength of $92.6 \mathrm{kHz}$ ) and with application of a strong ${ }^{1} \mathrm{H}$ signal decoupling by using the two-pulse phase modulation scheme. The spectra were recorded at a MAS spinning rate of $12 \mathrm{kHz}$. Sample spinning was performed using dry nitrogen gas. The recovery delay was set to $10 \mathrm{~s}$. Spectra were acquired at $20{ }^{\circ} \mathrm{C}$ (controlled by a Bruker BCU unit).

All sample preparation and handling were carried out in a glovebox under continuously purified argon atmosphere $\left(\mathrm{H}_{2} \mathrm{O}\right.$ and $\mathrm{O}_{2}$ levels were kept below $10 \mathrm{ppm}$ ).

To determine the nature of the Ti-containing species, thermodynamic calculations have been carried out using the HSC Chemistry software version 9.4.1. ${ }^{63}$ The calculations have been done based on the reactivity of $2 \mathrm{LiBH}_{4}+\mathrm{MgH}_{2}$ with $\mathrm{TiF}_{4}$ under different temperature and pressure conditions. The most favorable reactions have been identified through a combination of Gibbs minimization equilibrium with selected solid and gas species. The obtained results represent the ideal phase equilibrium compositions useful to predict the possible reaction mechanisms between the Li-RHC matrix and the additive involving solid products and gaseous species such as $\mathrm{B}_{2} \mathrm{H}_{6}$, $\mathrm{B}_{x} \mathrm{H}_{y}(x=5-12, y=5-14)$, and fluoride species. For all the calculations, the solid orthorhombic $\mathrm{LiBH}_{4}$ (Pnma) is taken into account. $\mathrm{Li}_{2} \mathrm{~B}_{12} \mathrm{H}_{12}$ was not taken into account due to the lack of available physicochemical data.

\section{RESULTS}

Volumetric and Calorimetric Measurements: Reaction Kinetic and Reaction Mechanism. The nonisothermal volumetric measurements of pristine $2 \mathrm{LiBH}_{4}+\mathrm{MgH}_{2}$ and $2 \mathrm{LiBH}_{4}+\mathrm{MgH}_{2}+0.1 \mathrm{TiF}_{4}$ samples are presented in Figure 1 .

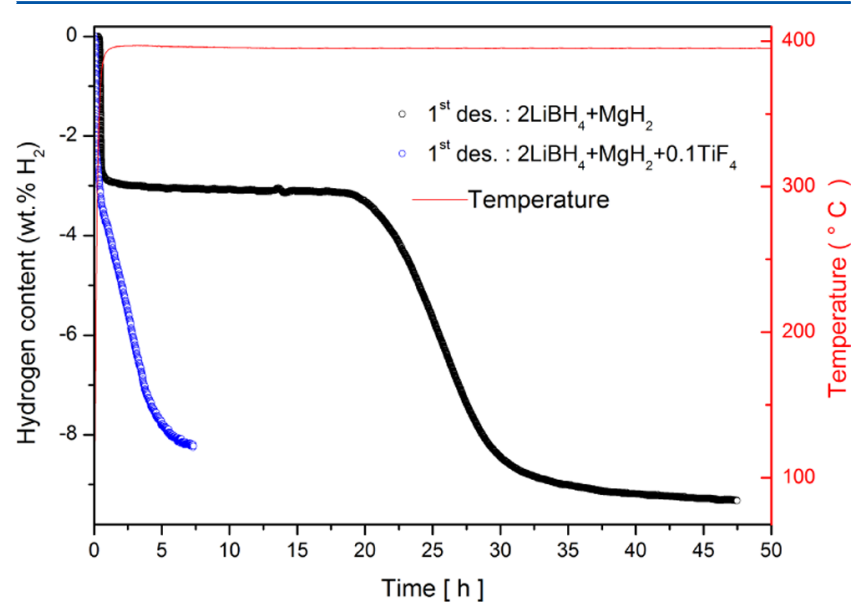

Figure 1. First nonisothermal dehydrogenation reaction from room temperature $(\mathrm{RT})$ to $400{ }^{\circ} \mathrm{C}$, heating rate $3{ }^{\circ} \mathrm{C} / \mathrm{min}$, and under $\mathrm{PH}_{2}=$ 4 bar $\mathrm{H}_{2}$ dehydrogenation for $2 \mathrm{LiBH}_{4}+\mathrm{MgH}_{2}$ and $2 \mathrm{LiBH}_{4}+\mathrm{MgH}_{2}+$ $0.1 \mathrm{TiF}_{4}$ hydride systems.

The dehydrogenation reaction of pristine $2 \mathrm{LiBH}_{4}+\mathrm{MgH}_{2}$ (Figure 1) evolves roughly in $20 \mathrm{~h}$. The reaction proceeds in two steps separated by a plateau phase where hydrogen is almost not released. Subsequently, the plateau phase extends the total reaction time by roughly $6.5 \mathrm{~h}$. The second step of the reaction ends the plateau phase, and it is completed after roughly $12 \mathrm{~h}$. The dehydrogenation processes of $2 \mathrm{LiBH}_{4}+$ $\mathrm{MgH}_{2}+0.1 \mathrm{TiF}_{4}$ (Figure 1) also shows two reaction steps. However, no plateau phase is observed and the overall reaction is completed after roughly $4 \mathrm{~h}$. By adding $10 \mathrm{~mol} \%$ of $\mathrm{TiF}_{4}$, the kinetic behavior of the first dehydrogenation is improved by a factor of $\sim 5$ in comparison with the pure hydride system. Coupled calorimetric-volumetric measurements during the first dehydrogenation of $2 \mathrm{LiBH}_{4}+\mathrm{MgH}_{2}+0.1 \mathrm{TiF}_{4}$ (Figure S1, Supporting Information) show that from $50{ }^{\circ} \mathrm{C}$ to about 360 ${ }^{\circ} \mathrm{C}$, the material does not release hydrogen. However, the phase transition of $\mathrm{LiBH}_{4}$ from orthorhombic to hexagonal structure, as well as the melting of the hexagonal structure, is seen in the calorimetric signal at about 120 and $270{ }^{\circ} \mathrm{C}$, respectively. ${ }^{25,64}$ Neither the structural phase transition nor the melting point of $\mathrm{LiBH}_{4}$ is affected by the presence of the used additive. The coupled calorimetric-volumetric measurements exhibit the same behavior as the volumetric measurement for $2 \mathrm{LiBH}_{4}+$ $\mathrm{MgH}_{2}+0.1 \mathrm{TiF}_{4}$ material (Figures S1 and1).

Furthermore, both materials were cycled twice and the results of the second cycle are shown in Figure 2A,B. These volumetric measurements exhibit proper reversibility of $2 \mathrm{LiBH}_{4}$ $+\mathrm{MgH}_{2}+0.1 \mathrm{TiF}_{4}$ system and still reduced hydrogenation $(\sim 1$ 

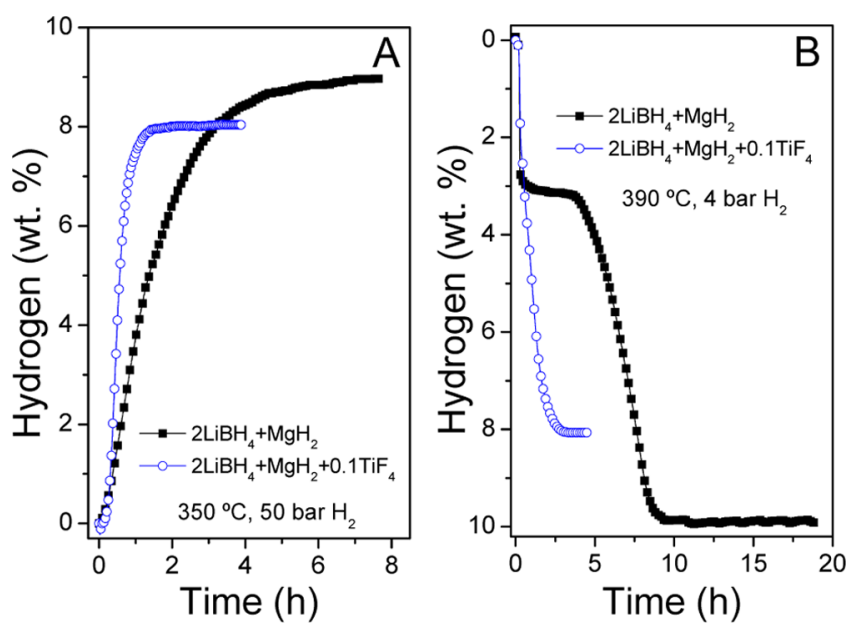

Figure 2. (A) Second hydrogenation and (B) second dehydrogenation for $2 \mathrm{LiBH}_{4}+\mathrm{MgH}_{2}$ and $2 \mathrm{LiBH}_{4}+\mathrm{MgH}_{2}+0.1 \mathrm{TiF}_{4}$ hydride systems. Isothermal hydrogenation/dehydrogenation at $350{ }^{\circ} \mathrm{C}$ under 50 bar $\mathrm{H}_{2}$ and $390{ }^{\circ} \mathrm{C}$ under 4 bar $\mathrm{H}_{2}$, respectively.

h) and dehydrogenation $(\sim 2 \mathrm{~h})$ times. Moreover, the hydrogen capacity remains constant at about $8 \mathrm{wt} \%$, which is lower than the corresponding value of the pristine material. This can be due to a possible interaction between the hydride matrix $\left(2 \mathrm{LiBH}_{4}+\mathrm{MgH}_{2}\right)$ and the $\mathrm{TiF}_{4}$ additive.

In Situ SR-XPD Measurements: Phase Transformation and Reaction Paths of Li-RHC. By means of in situ SR-XPD, reaction paths of crystalline phases of $2 \mathrm{LiBH}_{4}+\mathrm{MgH}_{2}+$ $0.1 \mathrm{TiF}_{4}$ were investigated (Figure 3 ). The starting material at room temperature consists of $\mathrm{LiBH}_{4}, \mathrm{MgH}_{2}$, and $\mathrm{LiF}$. By increasing the sample temperature, the diffraction peaks of the starting material become sharper and are shifted simultaneously toward the lower diffraction angles. These changes are due to recrystallization of the disordered milled material and enlarging of the respective unit cells owing to the increased temperature at the same time. At around $120^{\circ} \mathrm{C}$, the phase transformation of $\mathrm{LiBH}_{4}$ (from orthorhombic $o-\mathrm{LiBH}_{4}$ to hexagonal $h-\mathrm{LiBH}_{4}$ ) is observed. At $280{ }^{\circ} \mathrm{C}$, the diffraction peaks of $\mathrm{LiBH}_{4}$ suddenly diminish due to the melting of $\mathrm{LiBH}_{4}{ }^{66,67}$ These findings are in good agreement with the results obtained by coupled calorimetric-volumetric measurements of the first dehydrogenation of the doped system. During the first reaction step, $\mathrm{MgH}_{2}$ decomposes around $360{ }^{\circ} \mathrm{C}$ by forming metallic $\mathrm{Mg}$. In the second reaction step, at roughly $390^{\circ} \mathrm{C}$, the diffraction peaks of $\mathrm{Mg}$ decrease, whereas diffraction peaks of $\mathrm{MgB}_{2}$ phase start to appear. This indicates a mutual reaction between metallic $\mathrm{Mg}$ and liquid $\mathrm{LiBH}_{4}$. After dwelling for $30 \mathrm{~min}$ at $400{ }^{\circ} \mathrm{C}$ (Figure S2, Supporting Information), LiF phase and small amount of $\mathrm{MgO}$ phase are observed. These phases remain stable. $\mathrm{LiH}$ and $\mathrm{MgB}_{2}$ are observed as the main reaction products.

From the beginning, during the entire in situ SR-XPD measurement, no $\mathrm{TiF}_{4}$ or any $\mathrm{Ti}$-containing phases could be detected (Figures 3 and S2). This suggests that Ti or any $\mathrm{Ti}-$ containing compounds might be present in the sample in amorphous or nanocrystalline state. Therefore, X-ray absorption spectroscopy (XAS) measurements were carried out to determine the chemical state of $\mathrm{Ti}$ in the doped composite system. The great advantage of XAS technique is that it is independent of the crystallinity or the amorphous state of any given sample.

XAS Measurements: Chemical State and Local Environment of Titanium. Near-edge structure (XANES) of the XAS spectra of $\mathrm{Ti}$ in $2 \mathrm{LiBH}_{4}+\mathrm{MgH}_{2}+0.1 \mathrm{TiF}_{4}$ system at different hydrogenation state was extracted to determine the respective valance states of $\mathrm{Ti}$ (Figure S3, Supporting Information). $\mathrm{TiF}_{4}$ and $\mathrm{TiB}_{2}$ samples were measured as reference compounds. A comparison among $\mathrm{TiF}_{4}$ spectrum, $\mathrm{TiB}_{2}$ spectrum, and the spectra of $2 \mathrm{LiBH}_{4}+\mathrm{MgH}_{2}+0.1 \mathrm{TiF}_{4}$ samples at different hydrogenation states reveals significant changes in the oxidation state of $\mathrm{Ti}$ in the hydride matrix. The oxidation state of $\mathrm{Ti}$ in the milled sample shows high dissimilarity to the $\mathrm{TiF}_{4}$ reference sample. This suggests a change in the oxidation state of $\mathrm{Ti}$ already during the ball milling process. Thereafter, this oxidation state remains stable

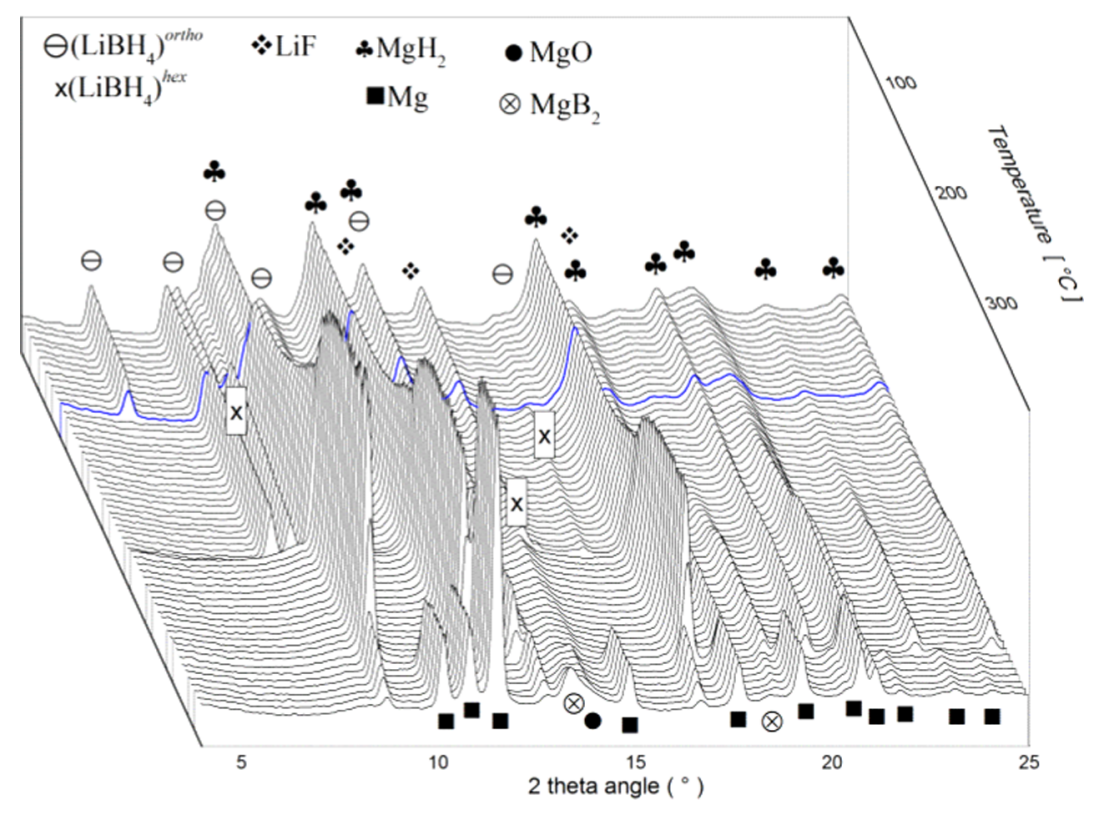

Figure 3. In situ SR-XPD for the first dehydrogenation reaction of $2 \mathrm{LiBH}_{4}+\mathrm{MgH}_{2}+0.1 \mathrm{TiF}_{4}$ under 4 bar $\mathrm{H}_{2}$ backpressure. The temperature was increased with a ramp of $3{ }^{\circ} \mathrm{C} / \mathrm{min}$ from RT to a maximum temperature of $400{ }^{\circ} \mathrm{C}$. 
upon further de/rehydrogenation processes. On the other hand, the XANES spectra of the doped sample at different hydrogenation states have high similarity to the reference spectrum of $\mathrm{TiB}_{2}$.

To further investigate the local environment of $\mathrm{Ti}$ atoms in the hydride matrix with respect to hydrogenation cycles, the extended X-ray absorption fine structure (EXAFS) $(\chi(k))$ region of the respective spectra was extracted and Fourier transformed. Figure 4 displays the unweighted $\chi(k)$ (in the $k$ range from 0 to $6 \AA$ ) for $2 \mathrm{LiBH}_{4}+\mathrm{MgH}_{2}+0.1 \mathrm{TiF}_{4}$ samples together with the reference spectra of $\mathrm{TiF}_{4}$ and $\mathrm{TiB}_{2}$.

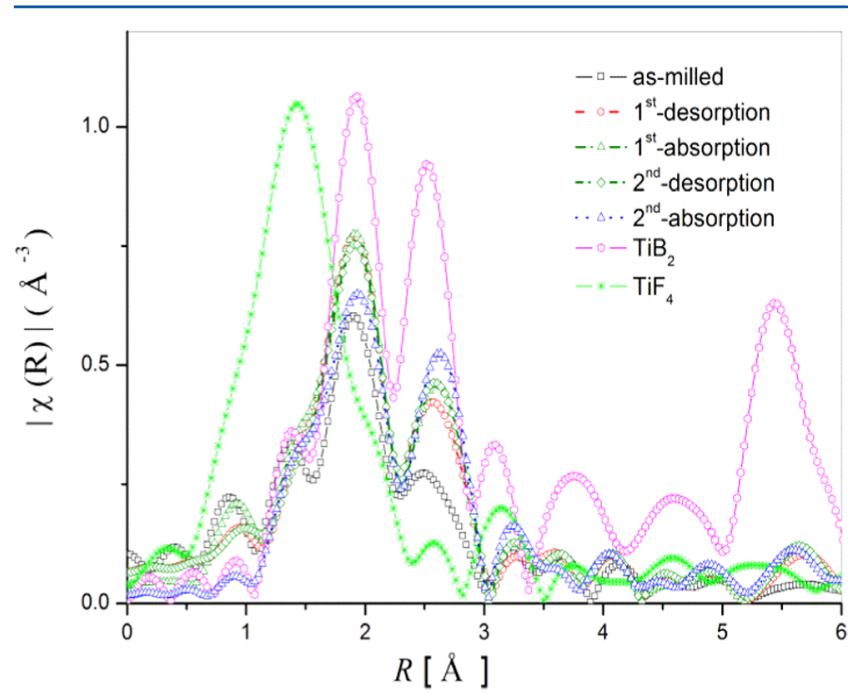

Figure 4. Fourier transformation of the EXAFS function in the $k$-range of $[0-6] \AA^{-1}$ of Ti-containing hydride matrix at different hydrogenation cycles together with the reference spectra.

The local environment of $\mathrm{Ti}$ in $2 \mathrm{LiBH}_{4}+\mathrm{MgH}_{2}$ composite system shows considerable changes after the ball milling process. The shift in the position of the main amplitude of $\mathrm{Ti}$ spectra of the samples relatively to $\mathrm{TiF}_{4}$ spectrum hints at the removal of fluorine atoms and the presence of other species as the nearest neighborhood (NN). Moreover, substantial drop in the amplitudes behind the principle amplitude around the central $\mathrm{Ti}$ atom, in comparison to the reference sample, is observed, indicating a high degree of disorder/dispersion of Ticontaining particles (nanosized structures). After first dehydrogenation, the principle EXAFS amplitudes are increased and remain relatively stable upon further de/rehydrogenation processes. This hints to a higher degree of ordering and/or slight growing of $\mathrm{Ti}$-containing structures relative to the ball milled samples. Furthermore, a comparison between the FTEXAF-spectra and the reference spectrum of $\mathrm{TiB}_{2}$ shows a good correspondence over the entire $R$-range, indicating the presence of $\mathrm{B}$ as $\mathrm{NN}$ of the central $\mathrm{Ti}$ atom.

To verify the formation of $\mathrm{TiB}_{2}$ in the doped samples at different hydrogenation states, $a b$ initio calculations were carried out using the FEFF6 program. ${ }^{61}$ The results of these calculation together with the EXAFS spectra of the samples are presented in Figure 5. In the calculation, the magnitudes of scattering amplitudes were not corrected for electron relaxation processes because the existence of $\mathrm{TiB}_{2}$ phase is the center of interest. FEFF calculations were performed assuming the crystalline state of $\mathrm{TiF}_{4}$ (space group Pnma; Cryst. Sys. Orthorhombic, ICSD \#78737) and the crystalline state of $\mathrm{TiB}_{2}$ (space group P6/mmm; Cryst. Sys. Hexagonal, ICSD \#30330).

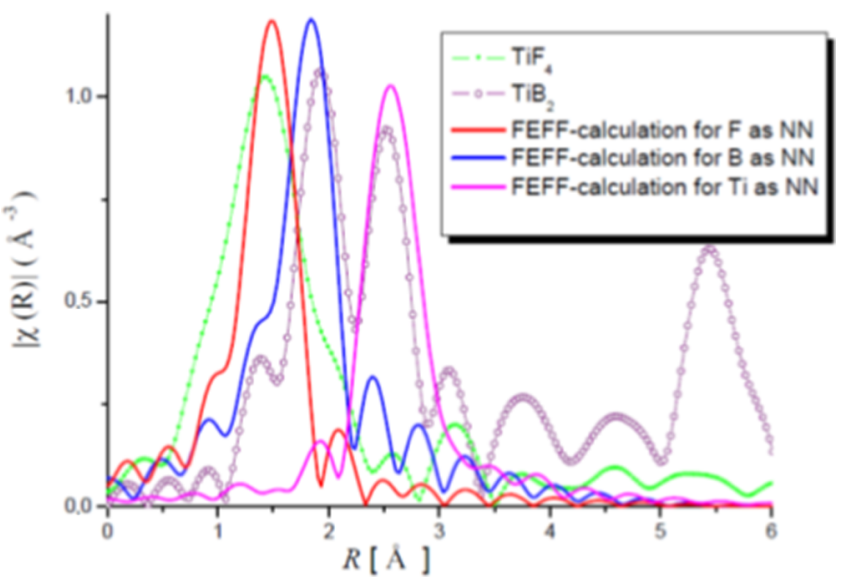

Figure 5. $R$-Distribution function of Ti-containing compounds in the hydride matrix after the first hydrogenation cycle and the corresponding FEFF fits.

The calculations allocate the first peak of $\mathrm{TiF}_{4}$ to fluorine backscattering amplitude, and the first and second peaks of $\mathrm{TiB}_{2}$ reference are addressed to boron and Ti backscattering amplitudes, respectively. This clarifies the transformation from $\mathrm{TiF}_{4}$ to $\mathrm{TiB}_{2}$ during the milling process of $2 \mathrm{LiBH}_{4}+\mathrm{MgH}_{2}+$ $0.1 \mathrm{TiF}_{4}$ material, which remains stable upon further de/ rehydrogenation cycles. To determine the size distribution of $\mathrm{TiB}_{2}$ particles in the hydride matrix, ASAXS measurements were conducted.

ASAXS Measurements: Size Distribution of $\mathrm{TiB}_{2}$ Particles. Anomalous Small-Angle X-ray Scattering (ASAXS) measurements in the vicinity of titanium K-absorption edge were carried out. The scattering intensities were collected at four precalculated X-ray energies (see Table 1, Experimental Section) to separate the resonant scattering curves of $\mathrm{Ti}$ containing structures in the hydride matrix at different hydrogenation stages. In Figure S4 (Supporting Information), the ASAXS curves of as-milled $2 \mathrm{LiBH}_{4}+\mathrm{MgH}_{2}+0.1 \mathrm{TiF}_{4}$ material are displayed. The anomalous scattering effect is clearly visible as the energy of incident beam increases (Figure S4inset plot, Supporting Information). At higher $q$ values, a stronger energy dependency of scattering intensities is observed. This is due to fluorescence and resonant Raman scattering. This incoherent scattering causes a constant background at the very high $q$-values of the scattering curves, which was removed before analyzing the data. This was done by subtracting a constant value from all the ASAXS curves, so that the scattering curves at very high $q$ values follow the Porod law afterward. ${ }^{65}$ Exemplarily, for all other curves, the resonant scattering curve of the as-milled sample together with its corresponding total scattering and mixed resonant scattering curve are shown in Figure S5 (Supporting Information). The resonant scattering curves were fitted by using the program Gnom. ${ }^{66,67}$ Distance distribution functions of $\mathrm{TiB}_{2}$ particles were calculated for all the samples, assuming spherical particles. The results of these calculations are presented in Figure 6. The maxima of the curves indicate the most frequent sizes of titanium-containing structures in the samples, whereas the tail of the distance distribution function denotes the largest titanium-containing structures.

In the as-milled $2 \mathrm{LiBH}_{4}+\mathrm{MgH}_{2}+0.1 \mathrm{TiF}_{4}$ sample, the most frequent $\mathrm{TiB}_{2}$ particle sizes are about $7 \mathrm{~nm}$, which grow up to $\sim 13 \mathrm{~nm}$ with the first dehydrogenation process. After the first 


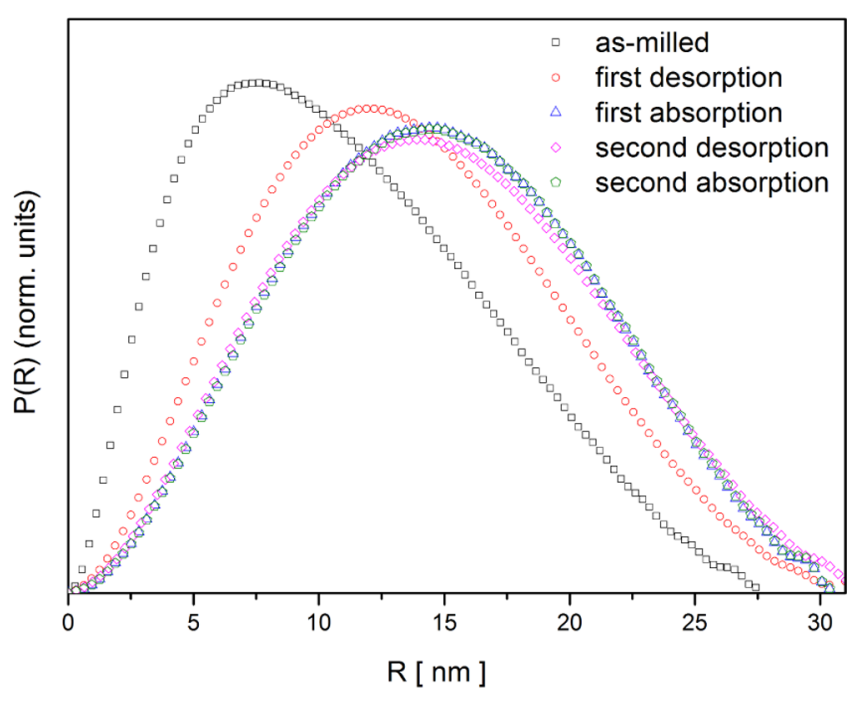

Figure 6. Distance-distribution curves of $2 \mathrm{LiBH}_{4}+\mathrm{MgH}_{2}+0.1 \mathrm{TiF}_{4}$ material at different hydrogenation states. absorption, a further growth of $\mathrm{Ti}$ structures from $13 \mathrm{~nm}$ to approximately $16 \mathrm{~nm}$ is observed, which remains stable upon further re/dehydrogenation cycling. The largest structures in the as-milled doped sample are about $27 \mathrm{~nm}$, which grow up to $\sim 30 \mathrm{~nm}$ with the desorption process and remain relatively stable upon further cycling.

TEM Observations: Morphological, Nanoscopic, Structural, and Phase Characterization. An electron diffraction pattern was taken to find the most feasible phases (Figure S6, Supporting Information). The rings are correlated with the $d_{(h k l)}$ values taking into account the intensity of the rings. As seen, $\mathrm{MgB}_{2}$ is detected, which is part of the matrix material. $\mathrm{MgO}$ is also present, and its presence can be attributed to the short exposure of the sample to air during TEM preparation procedure. $\mathrm{LiF}$ phase is detected as well, as it was shown by in situ SR-XPD measurements. Moreover, $\mathrm{TiB}_{2}$ is clearly detected by the presence of a ring, which can be only ascribed to $\mathrm{TiB}_{2}$ phase. In Figure 7, dark field (DF) TEM images and particles size distributions of $2 \mathrm{LiBH}_{4}+\mathrm{MgH}_{2}($ Figure $7 \mathrm{~A})$ and $2 \mathrm{LiBH}_{4}+$ $\mathrm{MgH}_{2}+0.1 \mathrm{TiF}_{4}$ (Figure 7B) samples after dehydrogenation
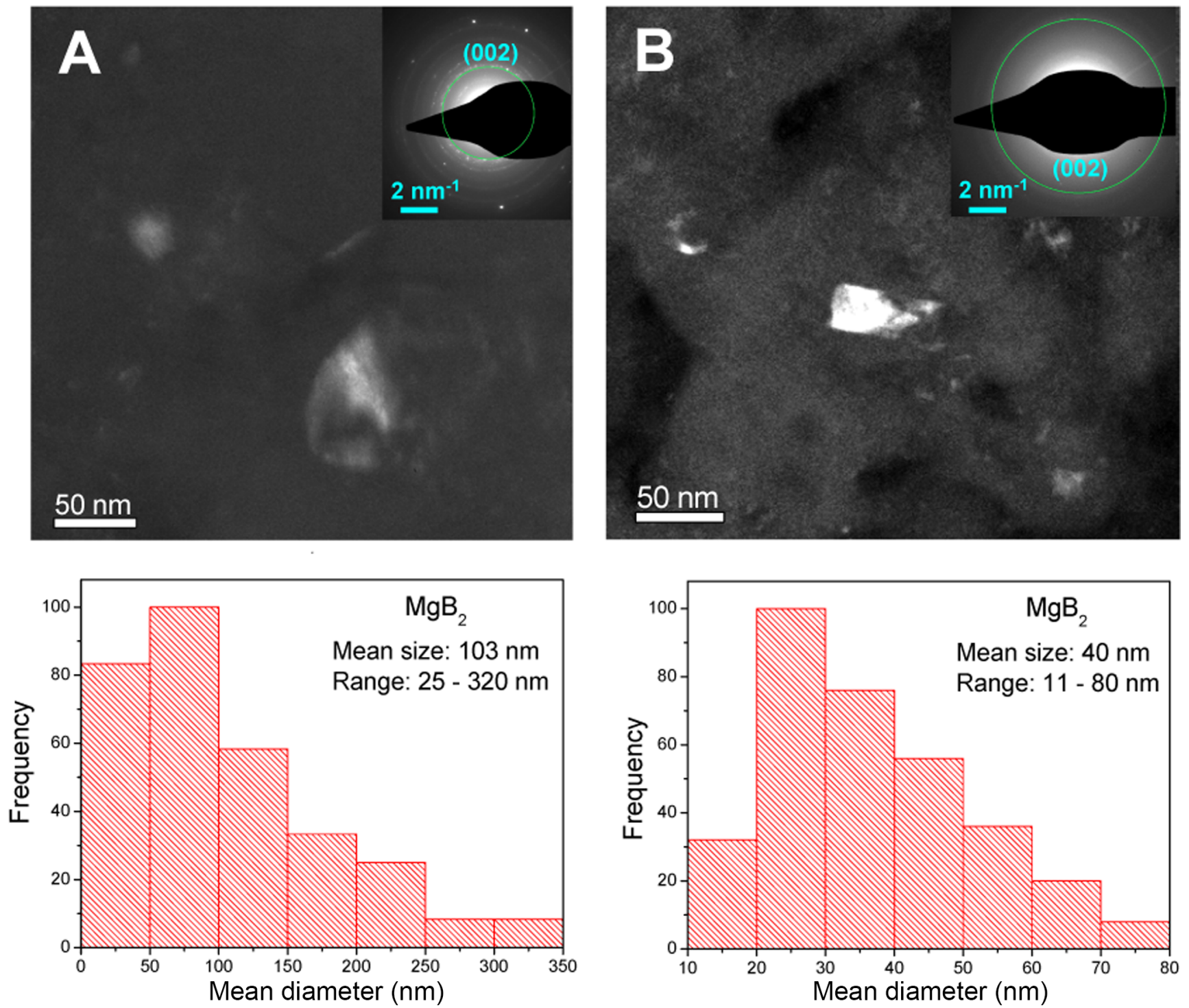

Figure 7. TEM in dark field (DF) modus (top) and $\mathrm{MgB}_{2}$ particle size distribution (bottom) in $2 \mathrm{LiBH}_{4}+\mathrm{MgH}_{2}\left(\right.$ left) and $2 \mathrm{LiBH}_{4}+\mathrm{MgH}_{2}+$ $0.1 \mathrm{TiF}_{4}$ (right). 

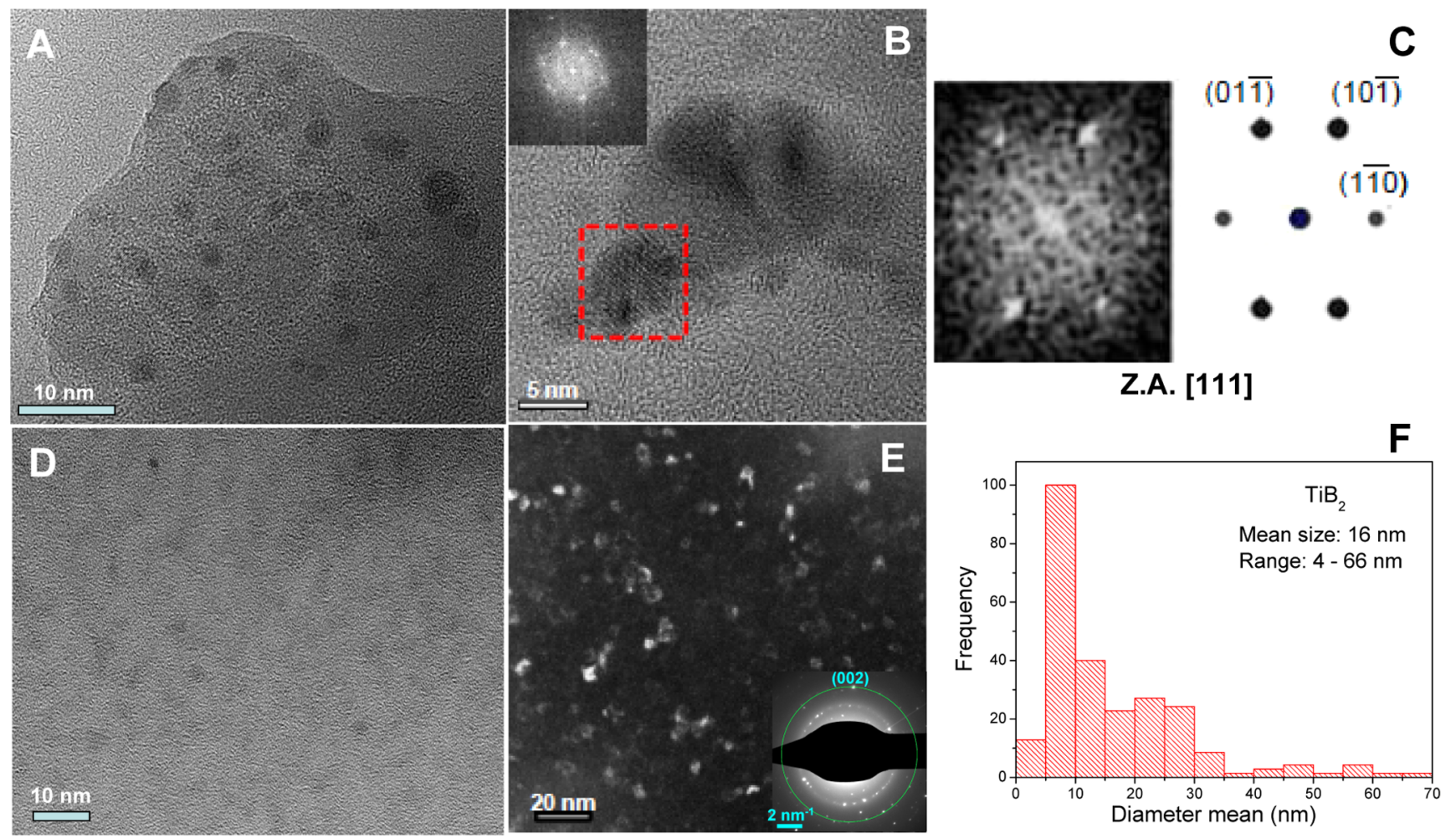

Figure 8. $2 \mathrm{LiBH}_{4}+\mathrm{MgH}_{2}+0.1 \mathrm{TiF}_{4}$ after the first dehydrogenation: (A, B) HR-TEM images. (C) FT and structure simulation. (D) Bright field. (E) Dark field in the shown bright field region and inset plot of the diffraction used for the DF. (F) Particle size distribution of TiB ${ }_{2}$.

are shown. It can be observed that the $\mathrm{MgB}_{2}$ particles in $2 \mathrm{LiBH}_{4}+\mathrm{MgH}_{2}$ sample are in average about $100 \mathrm{~nm}$ in size, whereas the average $\mathrm{MgB}_{2}$ particles in the doped sample are around $40 \mathrm{~nm}$. Figure 8 shows the HR-TEM images in bright field (Figure 8A,B,D) and in dark field (Figure 8E) for $2 \mathrm{LiBH}_{4}$ $+\mathrm{MgH}_{2}+0.1 \mathrm{TiF}_{4}$ material after the first dehydrogenation. Additionally, the Fourier transform of a particle (Figure 8B) and the corresponding simulation along with the resulting particle size distribution are exhibited (Figure 8C,F). From the HR-TEM images, it is possible to verify the presence of small particles of $\mathrm{TiB}_{2}$ in $2 \mathrm{LiBH}_{4}+\mathrm{MgH}_{2}+0.1 \mathrm{TiF}_{4}$ after the first dehydrogenation. The FT analysis (Figure $8 \mathrm{C}$ ) is in agreement with the electron pattern simulation, thus confirming that $\mathrm{TiB}_{2}$ particles are formed. This result is in accordance with the XAS analysis. From the DF image, size measurements have been carried out on numerous particles, leading to quite a reliable size distribution. The $\mathrm{TiB}_{2}$ structures show reduced sizes compared to those from $\mathrm{MgB}_{2}$ particles. As it is observed, the average particle size of $\mathrm{TiB}_{2}$ is about $16 \mathrm{~nm}$, with a range between 4 and $66 \mathrm{~nm}$. These $\mathrm{TiB}_{2}$ nanosizes are in good agreement with the ASAXS results (Figure 6).

\section{DISCUSSION}

The addition of $\mathrm{TiF}_{4}$ significantly improves the dehydrogenation/hydrogenation kinetics of $2 \mathrm{LiBH}_{4}+\mathrm{MgH}_{2}$ composite system (Figures 1 and S1, Supporting Information). During the first nonisothermal dehydrogenation, the presence of $\mathrm{TiF}_{4}$ precludes the long plateau period. This plateau phase is observed in pristine Li-RHC system and proceeds with almost no hydrogen release. It was reported before that this plateau phase might account for a slow incubation period required for the nucleation of $\mathrm{MgB}_{2}$ seeds. ${ }^{43}$ However, based on the experimental evidence, it was recently found that the plateau phase during the first dehydrogenation of the Li-RHC system is due to the slow formation of small amount of $\mathrm{Li}_{2} \mathrm{~B}_{12} \mathrm{H}_{12}$ from $\mathrm{LiBH}_{4}$ according to the reaction: $2 \mathrm{LiBH}_{4} \rightarrow(1 / 6) \mathrm{Li}_{2} \mathrm{~B}_{12} \mathrm{H}_{12}+$ $(5 / 3) \mathrm{LiH}+(13 / 6) \mathrm{H}_{2} \cdot{ }^{68-70}$ The formation of $\mathrm{Li}_{2} \mathrm{~B}_{12} \mathrm{H}_{12}$ partially blocks the interaction between $\mathrm{LiBH}_{4}$ and $\mathrm{Mg}$, and the formation of $\mathrm{MgB}_{2}$ is delayed. ${ }^{71}$ Moreover, the formation of gaseous $\mathrm{B}_{2} \mathrm{H}_{6}$, which further interacts with $\mathrm{LiH}$, can lead to the formation of $\mathrm{Li}_{2} \mathrm{~B}_{12} \mathrm{H}_{12}$. However, the presence of backpressure during dehydrogenation can kinetically avoid the formation of gaseous diborane $\left(\mathrm{B}_{2} \mathrm{H}_{6}\right)$ as an intermediate. ${ }^{17,72,73}$ To shed some light on the nature of the plateau region, $\mathrm{TiB}_{2}$ powder was ball milled for $10 \mathrm{~h}$. Subsequently, $0.1 \mathrm{TiB}_{2}$ (premilled powder) was added to $\mathrm{MgH}_{2}$, which was already milled for $5 \mathrm{~h}$. Thereafter, $\mathrm{LiBH}_{4}$ was added to the mixture and the entire composite system $\left(2 \mathrm{LiBH}_{4}+\mathrm{MgH}_{2}+0.1 \mathrm{TiB}_{2}\right)$ was further milled for additional $5 \mathrm{~h}$.

The dehydrogenation kinetics of $2 \mathrm{LiBH}_{4}+\mathrm{MgH}_{2}+0.1 \mathrm{TiB}_{2}$ system was measured by means of volumetric method. The results show (Figure S7, Supporting Information) that the plateau phase is significantly reduced by the presence of asmilled $\mathrm{TiB}_{2}$. However, the plateau region does not disappear completely. Therefore, it is possible to infer that there must be some formation of $\mathrm{Li}_{2} \mathrm{~B}_{12} \mathrm{H}_{12}$ coming from the initial $\mathrm{LiBH}_{4}$ decomposition and the amorphous boron in the starting material (Figure S8, Supporting Information). Despite this fact, the presence of $\mathrm{TiB}_{2}$ provides more centers for the nucleation of $\mathrm{MgB}_{2}$, promoting the early formation and fast growth of this phase and thus majorly avoiding an excessive growth of the $\mathrm{Li}_{2} \mathrm{~B}_{12} \mathrm{H}_{12}$ barrier that would delay the formation of $\mathrm{MgB}_{2}$. For the case of $2 \mathrm{LiBH}_{4}+\mathrm{MgH}_{2}+0.1 \mathrm{TiF}_{4}$, the nature of the in situ formed nanoparticles of $\mathrm{TiB}_{2}$ is more effective because the plateau region is totally suppressed (Figures 1 and S7). This can be ascribed to the nanostructured $\mathrm{TiB}_{2}$ and the better 
distribution of nucleation centers for $\mathrm{MgB}_{2}$. These experimental results and analyses allow inferring that the formation of $\mathrm{Li}_{2} \mathrm{~B}_{12} \mathrm{H}_{12}$ and the nucleation of $\mathrm{MgB}_{2}$ seeds are two competing reactions upon the decomposition of $\mathrm{LiBH}_{4}$ in the $\mathrm{Li}-\mathrm{RHC}$. Upon cycling, it is noticed that the presence of the additive causes a drop in the hydrogen capacity from about 10 wt $\% \mathrm{H}_{2}$ to 8 wt $\% \mathrm{H}_{2}$ in comparison to pristine $2 \mathrm{LiBH}_{4}+\mathrm{MgH}_{2}$ (Figure 2). Nevertheless, the enhanced kinetic behavior and hydrogen capacity of $8 \mathrm{wt} \%$ remain stable.

In previous works, it was found that the interaction of $3 \mathrm{LiBH}_{4} / 1 \mathrm{TiF}_{3}$ stoichiometric mixture during milling leads to the formation of volatile $\mathrm{Ti}\left(\mathrm{BH}_{4}\right)_{3}{ }^{74,75} \mathrm{Kang}$ et al. ${ }^{96}$ showed the formation of nanosized $\mathrm{TiB}_{2}$ by the interaction between $\mathrm{LiBH}_{4}$ and $\mathrm{TiF}_{3}$. They found that a one-step milling process leads to the partial formation of $\mathrm{TiB}_{2}$. However, a three-step method starting with a $1 \mathrm{LiBH}_{4} / 0.04 \mathrm{TiF}_{3}$ stoichiometric mixture provided the full conversion to nanosized $\mathrm{TiB}_{2}$. In this work, a one-step milling procedure provides the full conversion to nanosized $\mathrm{TiB}_{2}$ (Figures 4, 5, and 8) from the interaction between $2 \mathrm{LiBH}_{4}+\mathrm{MgH}_{2}$ material and $0.1 \mathrm{TiF}_{4}$ additive.

To understand the interactions between $2 \mathrm{LiBH}_{4}+\mathrm{MgH}_{2}$ composite material and $\mathrm{TiF}_{4}$, phase composition equilibrium calculations based on the Gibbs free energy minimization were carried out with the HSC Chemistry software. ${ }^{63}$ The calculations under different conditions such as mechanical milling, first dehydrogenation, and first hydrogenation were performed (Table S1, Supporting Information). The equilibrium calculations predict that after milling, the formation of $\mathrm{LiF}, \mathrm{TiB}_{2}$, and $\mathrm{B}$ is thermodynamically favored according to the reaction (4): $0.4 \mathrm{LiBH}_{4}+0.1 \mathrm{TiF}_{4} \rightarrow 0.4 \mathrm{LiF}+0.1 \mathrm{TiB}_{2}+0.2 \mathrm{~B}+$ $0.8 \mathrm{H}_{2(\mathrm{~g})}\left(\Delta \mathrm{G}_{298 \mathrm{~K}}=-57.2 \mathrm{~kJ}\right)$.

In situ SR-XPD shows the presence of $\mathrm{LiF}$ after milling (Figure 3). Moreover, after milling, the crystallite size of $\mathrm{MgH}_{2}$ in $2 \mathrm{LiBH}_{4}+\mathrm{MgH}_{2}+0.1 \mathrm{TiF}_{4}$ sample is further refined down to $8 \mathrm{~nm}$ in comparison with $15 \mathrm{~nm}$ for $2 \mathrm{LiBH}_{4}+\mathrm{MgH}_{2}$ (Supporting Information Figure S9, ex situ XRD). The NMR results (Figure S8, Supporting Information) evidence the presence of amorphous boron and boride compounds in the aspurchased $\mathrm{LiBH}_{4}$. For the as-milled $2 \mathrm{LiBH}_{4}+\mathrm{MgH}_{2}+0.1 \mathrm{TiF}_{4}$, the amount of amorphous boron increases. Moreover, mass spectroscopy measurements show the presence of hydrogen in the milling chamber atmosphere (Figure S10, Supporting Information). These results are in accordance with the proposed reaction (4). Upon dehydrogenation and hydrogenation, the experimental results (Figures 3-5, and 8) and the equilibrium thermodynamic calculation show that $\mathrm{LiF}$ and $\mathrm{TiB}_{2}$ remain stable under the applied conditions. This explains the reduction in the gravimetric hydrogen storage capacity of $2 \mathrm{LiBH}_{4}+\mathrm{MgH}_{2}+0.1 \mathrm{TiF}_{4}$ composite system in comparison to the pure Li-RHC. Furthermore, size distribution of $\mathrm{TiB}_{2}$ structures was determined via ASAXS measurements and TEM observations (Figures 6 and 8). Both methods show roughly a size distribution of $\mathrm{TiB}_{2}$ nanoparticles with sizes around $10-16 \mathrm{~nm}$. These $\mathrm{TiB}_{2}$ nanoparticles are most likely responsible for the heterogeneous nucleation and the growth of $\mathrm{MgB}_{2}$ phase during the dehydrogenation of $2 \mathrm{LiBH}_{4}-\mathrm{Mg}$. Calculations, carried out based on the mismatch theory, ${ }^{77,78}$ revealed two possible crystallographic matching planes between $\mathrm{TiB}_{2}$ and $\mathrm{MgB}_{2}\left(\mathrm{MgB}_{2}\{1010\} / / \mathrm{TiB}_{2}\{1010\}=1.9\right.$ and $\left.\mathrm{MgB}_{2}\{1011\} / / \mathrm{TiB}_{2}\{1011\}=4.5\right)$. These mismatch values are lower than $6 \%$, which is considered as the upper limit value. ${ }^{79}$ Therefore, $\mathrm{TiB}_{2}$ can provide two possible crystallographic nucleation planes for $\mathrm{MgB}_{2}$. This assumption is further indirectly verified by the results obtained via TEM observation of $\mathrm{MgB}_{2}$ particle size distributions in the matrix of pure and doped composite system (Figure 7). In the doped system, the average $\mathrm{MgB}_{2}$ particle size is about $40 \mathrm{~nm}$ and the maximum observed $\mathrm{MgB}_{2}$ particle size range is roughly $80 \mathrm{~nm}$, whereas in the pure material, the corresponding average size is about 100 $\mathrm{nm}$ and the maximum size is around $300 \mathrm{~nm}$. This observation can be explained by assuming the uniformly distributed $\mathrm{TiB}_{2}$ nanoparticles in the hydride matrix that act as nucleation centers for $\mathrm{MgB}_{2}$ phase during dehydrogenation. Thus, $\mathrm{MgB}_{2}$ seeds start to nucleate and grow around these nuclei. Due to the vast numbers of these nucleation centers, which are uniformly distributed in the material with additive, the nucleation of $\mathrm{MgB}_{2}$ starts to take place in numerous places in the interface of $\mathrm{LiBH}_{4} / \mathrm{Mg}$. This mechanism, indeed, leads to notably faster reaction kinetics and significantly smaller $\mathrm{MgB}_{2}$ structures, in comparison to the corresponding pure $\mathrm{Li}-\mathrm{RHC}$ system.

\section{CONCLUSIONS}

One-step in situ synthesis of nanosized $\mathrm{TiB}_{2}$ from the interaction between $\mathrm{LiBH}_{4}$ and $\mathrm{TiF}_{4}$ is observed. During the ball milling procedure, nanosized $\mathrm{TiB}_{2}$ is formed and remains stable upon dehydrogenation/hydrogenation cycling.

The presence of nanosized $\mathrm{TiB}_{2}$ notably improves the kinetic behavior of $2 \mathrm{LiBH}_{4}+\mathrm{MgH}_{2}$ system by reducing the dehydrogenation and hydrogenation times from $10-20 \mathrm{~h}$ to less than $3 \mathrm{~h}$ and from $8 \mathrm{~h}$ to about $1 \mathrm{~h}$, respectively. Moreover, the Li-RHC system doped with $0.1 \mathrm{TiF}_{4}$ shows a reversible hydrogen capacity of $8 \mathrm{wt} \%$. The observed kinetic improvement of the doped system accounts for its refined microstructure, homogeneous distribution of nanosized $\mathrm{TiB}_{2}$, and the feasibility of $\mathrm{TiB}_{2}$ to act as the nucleation interface for $\mathrm{MgB}_{2}$.

\section{ASSOCIATED CONTENT}

\section{S Supporting Information}

The Supporting Information is available free of charge on the ACS Publications website at DOI: 10.1021/acs.jpcc.8b02258.

Additional results for $2 \mathrm{LiBH}_{4}+\mathrm{MgH}_{2}+0.1 \mathrm{TiF}_{4}$; coupled volumetric and calorimetric HP-DSC, in situ SR-XRD for the dehydrogenation reaction at isothermal condition, XANES structure at different hydrogenation state, ASAXS scattering curves, TEM after dehydrogenation with the corresponding table of the reflections; MS measurements; volumetric measurements; nonisothermal dehydrogenation of $2 \mathrm{LiBH}_{4}+\mathrm{MgH}_{2}, 2 \mathrm{LiBH}_{4}+\mathrm{MgH}_{2}+$ $0.1 \mathrm{TiF}_{4}$, and $2 \mathrm{LiBH}_{4}+\left[\left(\mathrm{MgH}_{2}+0.1 \mathrm{TiB}_{2}\right)\right.$ premilled $]$ samples; thermodynamic equilibrium calculations; ex situ $\mathrm{XRD}$ and NMR of the as-purchased $\mathrm{LiBH}_{4}$ and the asmilled $2 \mathrm{LiBH}_{4}+\mathrm{MgH}_{2}+0.1 \mathrm{TiF}_{4}(\mathrm{PDF})$

\section{AUTHOR INFORMATION}

\section{Corresponding Author}

*E-mail: julian.puszkiel@hzg.de. Tel.: +4917621631783.

ORCID

Fahim Karimi: 0000-0001-6220-1463

Antonio Santoru: 0000-0003-2619-7481

Pau Nolis: 0000-0003-2360-1709 


\section{Author Contributions}

The authors of this manuscript substantially contributed to this work. The final version of this manuscript was reviewed by all the authors. This manuscript is submitted by agreement of all the authors.

\section{Notes}

The authors declare no competing financial interest.

\section{ACKNOWLEDGMENTS}

The authors thank CONICET (Consejo Nacional de Invetigaciones Cientificas y Técnicas), ANPCyT (Agencia Nacional de Promoción Científica y Tecnológica) PICT 2015-1865, CNEA (Comisión Nacional de Energia Atómica), for financial support to carry out this work. We would also like to thank the Metals Physics Division at HZG for providing the TEM devices. We thank HZB for the allocation of synchrotron radiation beamtime. The research leading to these results has received funding from the European Marie Curie Actions under ECOSTORE grant agreement no. 607040.

\section{ABBREVIATIONS}

RHC, reactive hydride composite; SR-XPD, synchrotron radiation X-ray powder diffraction; XAS, X-ray absorption spectroscopy; ASAXS, anomalous small-angle X-ray scattering; MS, mass spectroscopy

\section{REFERENCES}

(1) Züttel, A.; Borgschule, A.; Schlapbach, A. Hydrogen as a Future Energy Carrier; John Wiley \& Sons: New York, 2008.

(2) Schlapbach, L.; Züttel, A. Hydrogen-Storage Materials for Mobile Applications. Nature 2001, 414, 353.

(3) Schüth, F.; Bogdanovic, B.; Felderhoff, M. Light Metal Hydrides and Complex Hydrides for Hydrogen Storage. Chem. Commun. 2004, 2249-2258.

(4) Züttel, A.; Wenger, P.; Rentsch, S.; Sudan, P.; Mauron, P.; Emmenegger, C. $\mathrm{LiBH}_{4}$ a New Hydrogen Storage Material. J. Power Sources 2003, 118, 1-7.

(5) Züttel, A.; Rentsch, S.; Fischer, P.; Wenger, P.; Sudan, P.; Mauron, P.; Emmenegger, C. Hydrogen Storage Properties of $\mathrm{LiBH}_{4}$. J. Alloys Compd. 2003, 356-357, 515-520.

(6) Ohba, N.; Miwa, K.; Aoki, M.; Noritake, T.; Towata, S.-i.; Nakamori, Y.; Orimo, S.-i.; Züttel, A. First-Principles Study on the Stability of Intermediate Compounds of $\mathrm{LiBH}_{4}$. Phys. Rev. B 2006, 74, No. 075110.

(7) Au, M.; Jurgensen, A.; Zeigler, K. Modified Lithium Borohydrides for Reversible Hydrogen Storage (2). J. Phys. Chem. B 2006, 110, 26482-26487.

(8) Kang, X.-D.; Wang, P.; Ma, L.-P.; Cheng, H.-M. Reversible Hydrogen Storage in $\mathrm{LiBH}_{4}$ Destabilized by Milling with Al. Appl. Phys. A 2007, 89, 963.

(9) Hwang, S.-J.; Bowman, R. C.; Reiter, J. W.; Rijssenbeek; Soloveichik, G. L.; Zhao, J.-C.; Kabbour, H.; Ahn, C. C. Nmr Confirmation for Formation of $\left[\mathrm{B}_{12} \mathrm{H}_{12}\right]^{2-}$ Complexes During Hydrogen Desorption from Metal Borohydrides. J. Phys. Chem. C 2008, 112, 3164-3169.

(10) Zhang, Y.; Zhang, W.-S.; Fan, M.-Q.; Liu, S.-S.; Chu, H.-L.; Zhang, Y.-H.; Gao, X.-Y.; Sun, L.-X. Enhanced Hydrogen Storage Performance of $\mathrm{LiBH}_{4}-\mathrm{SiO}_{2}-\mathrm{TiF}_{3}$ Composite. J. Phys. Chem. C 2008, $112,4005-4010$.

(11) Mosegaard, L.; Møller, B.; Jørgensen, J.-E.; Filinchuk, Y.; Cerenius, Y.; Hanson, J. C.; Dimasi, E.; Besenbacher, F.; Jensen, T. R. Reactivity of $\mathrm{LiBH}_{4}$ : In Situ Synchrotron Radiation Powder X-Ray Diffraction Study. J. Phys. Chem. C 2008, 112, 1299-1303.

(12) Au, M.; Jurgensen, A. R.; Spencer, W. A.; Anton, D. L.; Pinkerton, F. E.; Hwang, S.-J.; Kim, C.; Bowman, R. C. Stability and
Reversibility of Lithium Borohydrides Doped by Metal Halides and Hydrides. J. Phys. Chem. C 2008, 112, 18661-18671.

(13) Xu, J.; Yu, X.; Zou, Z.; Li, Z.; Wu, Z.; Akins, D. L.; Yang, H. Enhanced Dehydrogenation of $\mathrm{LiBH}_{4}$ Catalyzed by Carbon-Supported Pt Nanoparticles. Chem. Commun. 2008, 5740-5742.

(14) Fang, Z.-Z.; Kang, X.-D.; Wang, P.; Cheng, H.-M. Improved Reversible Dehydrogenation of Lithium Borohydride by Milling with as-Prepared Single-Walled Carbon Nanotubes. J. Phys. Chem. C 2008, 112, 17023-17029.

(15) Xia, G. L.; Guo, Y. H.; Wu, Z.; Yu, X. B. Enhanced Hydrogen Storage Performance of $\mathrm{LiBH}_{4}-\mathrm{Ni}$ Composite. J. Alloys Compd. 2009, 479, 545-548.

(16) Caputo, R.; Züttel, A. First-Principles Study of the Paths of the Decomposition Reaction of $\mathrm{LiBH}_{4}$. Mol. Phys. 2010, 108, 1263-1276.

(17) Friedrichs, O.; Remhof, A.; Hwang, S. J.; Züttel, A. Role of $\mathrm{Li}_{2} \mathrm{~B}_{12} \mathrm{H}_{12}$ for the Formation and Decomposition of $\mathrm{LiBH}_{4}$. Chem. Mater. 2010, 22, 3265-3268.

(18) Ngene, P.; van Zwienen, M.; de Jongh, P. E. Reversibility of the Hydrogen Desorption from $\mathrm{LiBH}_{4}$ : A Synergetic Effect of Nanoconfinement and Ni Addition. Chem. Commun. 2010, 46, 8201-8203.

(19) Rude, L. H.; Groppo, E.; Arnbjerg, L. M.; Ravnsbæk, D. B.; Malmkjær, R. A.; Filinchuk, Y.; Baricco, M.; Besenbacher, F.; Jensen, T. R. Iodide Substitution in Lithium Borohydride, $\mathrm{LiBH}_{4}-$ LiI. J. Alloys Compd. 2011, 509, 8299-8305.

(20) Zavorotynska, O.; Corno, M.; Pinatel, E.; Rude, L. H.; Ugliengo, P.; Jensen, T. R.; Baricco, M. Theoretical and Experimental Study of $\mathrm{LiBH}_{4}-\mathrm{LiCl}$ Solid Solution. Crystals 2012, 2, 144.

(21) Shao, J.; Xiao, X.; Fan, X.; Zhang, L.; Li, S.; Ge, H.; Wang, Q.; Chen, L. Low-Temperature Reversible Hydrogen Storage Properties of $\mathrm{LiBH}_{4}$ : A Synergetic Effect of Nanoconfinement and Nanocatalysis. J. Phys. Chem. C 2014, 118, 11252-11260.

(22) Orimo, S.-I.; Nakamori, Y.; Ohba, N.; Miwa, K.; Aoki, M.; Towata, S.-i.; Züttel, A. Experimental Studies on Intermediate Compound of $\mathrm{LiBH}_{4}$. Appl. Phys. Lett. 2006, 89, No. 021920.

(23) Orimo, S.; Nakamori, Y.; Eliseo, J. R.; Züttel, A.; Jensen, C. M. Complex Hydrides for Hydrogen Storage. Chem. Rev. 2007, 107, 4111-4132.

(24) Mauron, P.; Buchter, F.; Friedrichs, O.; Remhof, A.; Bielmann, M.; Zwicky, C. N.; Züttel, A. Stability and Reversibility of Libh4. J. Phys. Chem. B 2008, 112, 906-910.

(25) Fedneva, E. M.; Alpatova, V. I.; Mikheeva, V. I. Transl. of Zh. Neorg. Khim. Russ. J. Inorg. Chem. 1964, 9, 826-827.

(26) Barkhordarian, G.; Klassen, T.; Bormann, R. German Patent DE1022004/061286, 2004.

(27) Vajo, J. J.; Skeith, S. L.; Mertens, F. Reversible Storage of Hydrogen in Destabilized $\mathrm{LiBH}_{4}$. J. Phys. Chem. B 2005, 109, 37193722 .

(28) Bösenberg, U.; et al. Hydrogen Sorption Properties of Mgh2Libh4 Composites. Acta Mater. 2007, 55, 3951-3958.

(29) Pistidda, C.; et al. Effect of the Partial Replacement of Cah2 with Caf2 in the Mixed System $\mathrm{CaH}_{2}+\mathrm{MgB}_{2}$. J. Phys. Chem. C 2014, 118, 28409-28417.

(30) Bergemann, N.; Pistidda, C.; Milanese, C.; Emmler, T.; Karimi, F.; Chaudhary, A. L.; Chierotti, M. R.; Klassen, T.; Dornheim, M. $\mathrm{Ca}\left(\mathrm{BH}_{4}\right)_{2}-\mathrm{Mg}_{2} \mathrm{NiH}_{4}$ : On the Pathway to a $\mathrm{Ca}\left(\mathrm{BH}_{4}\right)_{2}$ System with a Reversible Hydrogen Cycle. Chem. Commun. 2016, 52, 4836-4839.

(31) Sale, M.; Pistidda, C.; Taras, A.; Napolitano, E.; Milanese, C.; Karimi, F.; Dornheim, M.; Garroni, S.; Enzo, S.; Mulas, G. In Situ Synchrotron Radiation Powder X-Ray Diffraction Study of the $2 \mathrm{LiNH}_{2}$ $+\mathrm{LiH}+\mathrm{KBH}_{4}$ System. J. Alloys Compd. 2013, 580, S278-S281.

(32) Gosalawit-Utke, R; et al. $\mathrm{LiBH}_{4}-\mathrm{MgH}_{2}$ in a ResorcinolFurfural Carbon Aerogel Scaffold for Reversible Hydrogen Storage. J. Phys. Chem. C 2012, 116, 1526-1534.

(33) Cao, $\mathrm{H}$; ; et al. Kinetic Alteration of the $6 \mathrm{Mg}\left(\mathrm{NH}_{2}\right)_{2}-9 \mathrm{LiH}-$ $\mathrm{LiBH}_{4}$ System by Co-Adding $\mathrm{YCl}_{3}$ and $\mathrm{Li}_{3} \mathrm{~N}$. Phys. Chem. Chem. Phys. 2017, 19, 32105-32115.

(34) Carrillo-Bucio, J. L.; Saldan, I.; Pistidda, C.; Karimi, F.; SuárezAlcántara, K.; Dornheim, M.; Klassen, T. Hydrogenation Study of 
$\mathrm{NaF} / \mathrm{NaH} / \mathrm{MgB}_{2}$ Reactive Hydride Composites. J. Phys. Chem. C 2017, 121, 4093-4102.

(35) Santoru, A.; et al. $\mathrm{KNH}_{2}-\mathrm{KH}$ : A Metal Amide-Hydride Solid Solution. Chem. Commun. 2016, 52, 11760-11763.

(36) Karimi, F.; et al. Structural and Kinetic Investigation of the Hydride Composite $\mathrm{Ca}\left(\mathrm{BH}_{4}\right)_{2}+\mathrm{MgH}_{2}$ System Doped with $\mathrm{Nbf5}$ for Solid-State Hydrogen Storage. Phys. Chem. Chem. Phys. 2015, 17, 27328-27342.

(37) Karimi, F.; Pranzas, P. K.; Hoell, A.; Vainio, U.; Welter, E.; Raghuwanshi, V. S.; Pistidda, C.; Dornheim, M.; Klassen, T.; Schreyer, A. Structural Analysis of Calcium Reactive Hydride Composite for Solid State Hydrogen Storage. J. Appl. Crystallogr. 2014, 47, 67-75.

(38) Gosalawit-Utke, R.; Milanese, C.; Nielsen, T. K.; Karimi, F.; Saldan, I.; Pranzas, K.; Jensen, T. R.; Marini, A.; Klassen, T.; Dornheim, M. Nanoconfined $2 \mathrm{LiBH}_{4}-\mathrm{MgH}_{2}$ for Reversible Hydrogen Storages: Reaction Mechanisms, Kinetics and Thermodynamics. Int. J. Hydrogen Energy 2013, 38, 1932-1942.

(39) Puszkiel, J.; et al. Sorption Behavior of the $\mathrm{MgH}_{2}-\mathrm{Mg}_{2} \mathrm{FeH}_{6}$ Hydride Storage System Synthesized by Mechanical Milling Followed by Sintering. Int. J. Hydrogen Energy 2013, 38, 14618-14630.

(40) Pinkerton, F. E.; Meyer, M. S.; Meisner, G. P.; Balogh, M. P.; Vajo, J. J. Phase Boundaries and Reversibility of $\mathrm{LiBH}_{4} / \mathrm{MgH}_{2}$ Hydrogen Storage Material. J. Phys. Chem. C 2007, 111, 12881-12885.

(41) Bösenberg, U.; Ravnsbæk, D. B.; Hagemann, H.; D’Anna, V.; Minella, C. B.; Pistidda, C.; van Beek, W.; Jensen, T. R.; Bormann, R.; Dornheim, M. Pressure and Temperature Influence on the Desorption Pathway of the $\mathrm{LiBH}_{4}-\mathrm{MgH}_{2}$ Composite System. J. Phys. Chem. C 2010, 114, 15212-15217.

(42) Puszkiel, J.; et al. Hydrogen Storage in $\mathrm{Mg}-\mathrm{LiBH}_{4}$ Composites Catalyzed by $\mathrm{FeF}_{3}$. J. Power Sources 2014, 267, 799-811.

(43) Bösenberg, U.; et al. Role of Additives in $\mathrm{LiBH}_{4}-\mathrm{MgH}_{2}$ Reactive Hydride Composites for Sorption Kinetics. Acta Mater. 2010, 58, 3381-3389.

(44) Sun, T.; Wang, H.; Zhang, Q.; Sun, D.; Yao, X.; Zhu, M. Synergetic Effects of Hydrogenated $\mathrm{Mg}_{3} \mathrm{La}$ and $\mathrm{TiCl}_{3}$ on the Dehydrogenation of $\mathrm{LiBH}_{4}$. J. Mater. Chem. 2011, 21, 9179-9184.

(45) Mao, J.; Guo, Z.; Yu, X.; Liu, H. Improved Reversible Dehydrogenation of $2 \mathrm{LiBH}_{4}+\mathrm{MgH}_{2}$ System by Introducing $\mathrm{Ni}$ Nanoparticles. J. Mater. Res. 2011, 26, 1143-1150.

(46) Deprez, E.; Muñoz-Márquez, M. A.; Haro, M. C. J. d; Palomares, F. J.; Soria, F.; Dornheim, M.; Bormann, R.; Fernández, A. Combined X-Ray Photoelectron Spectroscopy and Scanning Electron Microscopy Studies of the $\mathrm{LiBH}_{4}-\mathrm{MgH}_{2}$ Reactive Hydride Composite with and without a Ti-Based Additive. J. Appl. Phys. 2011, 109, No. 014913.

(47) Deprez, E.; Justo, A.; Rojas, T. C.; López-Cartés, C.; Bonatto Minella, C.; Bösenberg, U.; Dornheim, M.; Bormann, R.; Fernández, A. Microstructural Study of the $\mathrm{LiBH}_{4}-\mathrm{MgH}_{2}$ Reactive Hydride Composite with and without Ti-Isopropoxide Additive. Acta Mater. 2010, 58, 5683-5694.

(48) Kou, H.; Xiao, X.; Li, J.; Li, S.; Ge, H.; Wang, Q.; Chen, L. Effects of Fluoride Additives on Dehydrogenation Behaviors of 2 $\mathrm{LiBH}_{4}+\mathrm{MgH}_{2}$ System. Int. J. Hydrogen Energy 2012, 37, 1021-1026.

(49) Xiao, X.; Shao, J.; Chen, L.; Kou, H.; Fan, X.; Deng, S.; Zhang, L.; Li, S.; Ge, H.; Wang, Q. Effects of $\mathrm{NbF}_{5}$ Addition on the De/ Rehydrogenation Properties of $2 \mathrm{LiBH}_{4} / \mathrm{MgH}_{2}$ Hydrogen Storage System. Int. J. Hydrogen Energy 2012, 37, 13147-13154.

(50) Pranzas, P. K.; et al. Characterization of Hydrogen Storage Materials and Systems with Photons and Neutrons. Adv. Eng. Mater. 2011, 13, 730-736.

(51) Fan, X.; Xiao, X.; Chen, L.; Wang, X.; Li, S.; Ge, H.; Wang, Q. High Catalytic Efficiency of Amorphous Tib2 and $\mathrm{NbB}_{2}$ Nanoparticles for Hydrogen Storage Using the $2 \mathrm{LiBH}_{4}-\mathrm{MgH}_{2}$ System. J. Mater. Chem. A 2013, 1, 11368-11375.

(52) Deprez, E.; Muñoz-Márquez, M. A.; Roldán, M. A.; Prestipino, C.; Palomares, F. J.; Minella, C. B.; Bösenberg, U.; Dornheim, M.; Bormann, R.; Fernández, A. Oxidation State and Local Structure of TiBased Additives in the Reactive Hydride Composite $2 \mathrm{LiBH}_{4}+\mathrm{MgH}_{2}$. J. Phys. Chem. C 2010, 114, 3309-3317.
(53) Hammersley, A. P. Fit2d: An Introduction and Overview; ESRF: France, 1997.

(54) Bieder, H.; Hoell, A.; Mokrani, L.; Zizak, I. DE102006029449, 2007.

(55) Hoell, A.; Tatchev, D.; Haas, S.; Haug, J.; Boesecke, P. On the Determination of Partial Structure Functions in Small-Angle Scattering Exemplified by Al89ni6la5 Alloy. J. Appl. Crystallogr. 2009, 42, 323325.

(56) Cromer, D. T.; Liberman, D. Relativistic Calculation of Anomalous Scattering Factors for X Rays. J. Chem. Phys. 1970, 53, 1891-1898.

(57) Vainio, U. Neutrons and Synchrotron Radiation in Engineering Materials Science: From Fundamentals to Applications, 2nd ed.; John Wiley \& Sons, 2017; Vol. 217-225.

(58) Goerigk, G.; Huber, K.; Schweins, R. Probing the Extent of the $\mathrm{Sr}^{2+}$ Ion Condensation to Anionic Polyacrylate Coils: A Quantitative Anomalous Small-Angle X-Ray Scattering Study. J. Chem. Phys. 2007, 127, No. 154908.

(59) Ravel, B.; Newville, M. Athena, Artemis, Hephaestus: Data Analysis for X-Ray Absorption Spectroscopy Using Ifeffit. J. Synchrotron Radiat. 2005, 12, 537-541.

(60) i-TEM (License $\mathrm{N}^{\circ}$ A2382500).

(61) Micrograph Digital (License $\mathrm{N}^{\circ}$ 90294175).

(62) JEMs (License $\mathrm{N}^{\circ}$ Ieb59ybdflumh).

(63) Outokumpu HSC Chemistry for Windows, v., Outotec.

(64) Nakagawa, T.; Ichikawa, T.; Hanada, N.; Kojima, Y.; Fujii, H. Thermal Analysis on the $\mathrm{Li}-\mathrm{Mg}-\mathrm{B}-\mathrm{H}$ Systems. J. Alloys Compd. 2007, 446-447, 306-309.

(65) Porod, G. Die Röntgenkleinwinkelstreuung Von Dichtgepackten Kolloiden Systemen; Springer-Verlag: Berlin, 1951; Vol. 124.

(66) Svergun, D. Determination of the Regularization Parameter in Indirect-Transform Methods Using Perceptual Criteria. J. Appl. Crystallogr. 1992, 25, 495-503.

(67) Semenyuk, A. V.; Svergun, D. I. Gnom - a Program Package for Small-Angle Scattering Data Processing. J. Appl. Crystallogr. 1991, 24, 537-540.

(68) Yan, Y.; Li, H.-W.; Maekawa, H.; Miwa, K.; Towata, S.-i.; Orimo, S.-i. Formation of Intermediate Compound $\mathrm{Li}_{2} \mathrm{~B}_{12} \mathrm{H}_{12}$ During the Dehydrogenation Process of the $\mathrm{LiBH}_{4}-\mathrm{MgH}_{2}$ System. J. Phys. Chem. C 2011, 115, 19419-19423.

(69) Kim, K.-B.; Shim, J.-H.; Park, S.-H.; Choi, I.-S.; Oh, K. H.; Cho, Y. W. Dehydrogenation Reaction Pathway of the $\mathrm{LiBH}_{4}-\mathrm{MgH}_{2}$ Composite under Various Pressure Conditions. J. Phys. Chem. C 2015, 119, 9714-9720.

(70) Puszkiel, J. A.; Castro Riglos, M. V.; Karimi, F.; Santoru, A.; Pistidda, C.; Klassen, T.; Bellosta von Colbe, J. M.; Dornheim, M. Changing the Dehydrogenation Pathway of $\mathrm{LiBH}_{4}-\mathrm{MgH}_{2}$ via Nanosized Lithiated $\mathrm{TiO}_{2}$. Phys. Chem. Chem. Phys. 2017, 19, 74557460.

(71) White, J. L.; Newhouse, R. J.; Zhang, J. Z.; Udovic, T. J.; Stavila, V. Understanding and Mitigating the Effects of Stable DodecahydroCloso-Dodecaborate Intermediates on Hydrogen-Storage Reactions. J. Phys. Chem. C 2016, 120, 25725-25731.

(72) Kim, K.-B.; Shim, J.-H.; Cho, Y. W.; Oh, K. H. PressureEnhanced Dehydrogenation Reaction of the $\mathrm{LiBH}_{4}-\mathrm{YH}_{3}$ Composite. Chem. Commun. 2011, 47, 9831-9833.

(73) Kostka, J.; Lohstroh, W.; Fichtner, M.; Hahn, H. Diborane Release from $\mathrm{LiBH}_{4} /$ Silica-Gel Mixtures and the Effect of Additives. J. Phys. Chem. C 2007, 111, 14026-14029.

(74) Fang, Z. Z.; Ma, L. P.; Kang, X. D.; Wang, P. J.; Wang, P.; Cheng, H. M. In Situ Formation and Rapid Decomposition of $\mathrm{Ti}\left(\mathrm{BH}_{4}\right)_{3}$ by Mechanical Milling $\mathrm{LiBH}_{4}$ with $\mathrm{TiF}_{3}$. Appl. Phys. Lett. 2009, 94, No. 044104.

(75) Callini, E.; Szilagyi, P. A.; Paskevicius, M.; Stadie, N. P.; Rehault, J.; Buckley, C. E.; Borgschulte, A.; Zuttel, A. Stabilization of Volatile $\mathrm{Ti}\left(\mathrm{BH}_{4}\right)_{3}$ by Nano-Confinement in a Metal-Organic Framework. Chem. Sci. 2016, 7, 666-672.

(76) Kang, X.; Wang, K.; Zhong, Y.; Yang, B.; Wang, P. A Novel Three-Step Method for Preparation of a Tib2-Promoted $\mathrm{LiBH}_{4}-\mathrm{MgH}_{2}$ 
Composite for Reversible Hydrogen Storage. Phys. Chem. Chem. Phys. 2013, 15, 2153-2158.

(77) Zhang, M.-X.; Kelly, P. M. Edge-to-Edge Matching and Its Applications: Part I. Application to the Simple Hcp/Bcc System. Acta Mater. 2005, 53, 1073-1084.

(78) Zhang, M.-X.; Kelly, P. M. Edge-to-Edge Matching and Its Applications: Part Ii. Application to $\mathrm{Mg}-\mathrm{Al}, \mathrm{Mg}-\mathrm{Y}$ and $\mathrm{Mg}-\mathrm{Mn}$ Alloys. Acta Mater. 2005, 53, 1085-1096.

(79) Zhang, M.-X.; Kelly, P. M. Edge-to-Edge Matching Model for Predicting Orientation Relationships and Habit Planes-the Improvements. Scr. Mater. 2005, 52, 963-968. 